


DIREITO

\title{
O DIREITO À INFORMAÇÃO E O ACESSO A DOCUMENTOS PÚBLICOS DA DITADURA MILITAR: A PROTEÇÃO PELA JURISDIÇÃO CONSTITUCIONAL
}

João Francisco da Mota Junior ${ }^{1}$

\section{RESUMO}

0 presente trabalho questiona como a jurisdição constitucional contribui - ou contribuiu - para a proteção do direito à informação referente aos documentos públicos da ditadura militar, por meio da análise empírica do RMS n 23036 do STF e da ADPF $n^{\circ} 153$. A questão ao envolver a garantia do acesso a documentos do período do regime militar se reporta a princípios constitucionais e basilares da sociedade contemporânea, o que, sem dúvida, inclui o direito fundamental à informação e o direito à verdade. Nos referidos julgamentos, anteriores à Lei de Acesso à Informação, o STF embora afirme faltar norma regulamentadora para 0 exercício do direito à informação (art. 5º, XXXIII, $\mathrm{CF}$ ), utiliza-se de princípios e interpretação para concessão e garantia desse direito, como jurisdição constitucional.

\section{PALAVRAS-CHAVE}

Direito à Informação. Acesso a Documentos Públicos. Ditadura Militar. Jurisdição Constitucional. 


\section{ABSTRACT}

This paper asks how the constitutional jurisdiction contributes - or helped - for the protection of the right to information for the public documents of the military dictatorship, through empirical analysis of RMS No. 23036 STF and ADPF No. 153. The question to involve ensuring access to the military regime period of the documents relates to constitutional and fundamental principles of contemporary society, which undoubtedly includes the fundamental right to information and the right to truth. In those judgments, prior to the

\section{RESUMEN}

En este trabajo se pregunta cómo contribuye - o contribuyó - la jurisdicción constitucional para la protección del derecho a la información relacionada a los documentos públicos de la dictadura militar, a través del análisis empírico de RMS Nº. 23036 STF y ADPF Nº. 153. La cuestión de involucrar y garantizar el acceso a la época del régimen militar de los documentos, se refiere a los principios constitucionales y fundamentales de la sociedad contemporánea, lo que sin duda incluye el derecho fundamental a la información y el derecho a la verdad. En dichas sentencias, antes de la Ley de Ac-
Access to Information Act, the Supreme Court while claiming missing regulatory standard for the exercise of the right to information (art. 5, XXXIII, CF), uses principles and interpretation to grant and guarantee this right, as constitutional jurisdiction.

\section{KEYWORDS}

Right to Information. Access to Public Documents. Military Dictatorship. Constitutional Jurisdiction.

ceso a la Información, la Corte Suprema brasileña aunque afirme faltar norma reglamentaria para el ejercicio del derecho a la información (art. 5, XXXIII, CF), utiliza los principios y la interpretación para otorgar y garantizar este derecho, como jurisdicción constitucional.

\section{PALABRAS CLAVE}

Derecho a la Información; El acceso a los Documentos Públicos; La Dictadura Militar; La Jurisdicción Constitucional. 


\section{INTRODUÇÃO}

0 direito à informação, previsto no art. $5^{\circ}, \mathrm{XXXIII}$ da Constituição Federal é uma garantia intrínseca aos Estados Democráticos, como direito fundamental, encontrando-se ainda reconhecido em diversos tratados internacionais.

O dispositivo constitucional trata-se de norma de eficácia limitada, uma vez que necessita de ação do legislador para que possa alcançar os seus reais e finalísticos efeitos, ainda de questionável aplicabilidade direta e imediata.

Somente com a Lei de Acesso à Informação - Lei $n^{0} 12.527 / 2011$ - que o direito à informação veio a ser efetivamente regulamentado, em que pese o reconhecimento de alguns normativos que asseguravam ao indivíduo e disciplinavam determinados acessos a informações públicas e privadas.

Assim, como era exercido o direito à informação antes da referida lei ante a falta dessa regulamentação constitucional do art. $5^{\circ}$, XXXIII? Que garantias e mecanismos existiam para sua efetivação? Qual o tratamento dado às informações públicas? E, em especial, os documentos relativos à ditadura militar?

Diante dessas indagações, surge a seguinte problemática: como a jurisdição constitucional contribui - ou contribuiu - para a proteção do direito à informação referente aos documentos públicos da ditadura militar?

Na tentativa de responder ao cerne central deste trabalho, sem pretender esgotar o tema, toma-se por parâmetro a análise do Recurso Ordinário em Mandado de Segurança ${ }^{0} 23.036$ do STF e da Arguição de Descumprimento de Preceito Fundamental (ADPF) nº 153.

Ambos os julgados são anteriores à Lei de Acesso à Informação (LAI), e por meio deles, pode-se identificar a importância da jurisdição constitucional na proteção de direitos.
A questão ao envolver a garantia do acesso a documentos públicos da ditadura militar se reporta a princípios constitucionais e basilares da sociedade contemporânea, o que, sem dúvida, está incluído o direito à informação.

\section{DIREITO FUNDAMENTAL À INFORMAÇÃO}

\subsection{DIREITO À INFORMAÇÃO COMO DIREITO FUNDAMENTAL}

0 direito à informação previsto no art. $5^{\circ}, \mathrm{XXXIII} \mathrm{da}$ CF é uma garantia fundamental e intrínseca aos Estados Democráticos, como já previsto na Declaração Universal dos Direitos Humanos de 1948 (art. XIX2), bem como em tratados e convenções internacionais, como o Pacto Internacional de Direitos Civis e Políticos (art. 19, ONU-1966), a Convenção Interamericana de Direitos Humanos (art. 13, OEA-1969), a Carta Africana de Direitos Humanos e dos Povos (art. 9, OUA1981) e Convenção Europeia sobre Direitos Humanos (art. 10, 1950), a exemplo.

Em época mais remota, a Lei de Liberdade de Imprensa (Freedom of the Press Act) suíça, de 1766 é tida como a primeira lei que tem um capítulo específico sobre a natureza pública dos documentos oficiais, prevendo que todo indivíduo tem o direito de acessá-los, salvo aqueles classificados como secretos, ainda que haja alguns registros antecedentes como na China, onde a tradição humanista já exigia que os governantes prestassem "contas" de suas ações, assim como previu a Declaração dos Direitos do Homem e do Cidadão de 1789 (arts. 11, 14 e 15).

No ano de 1888 surgiu a Lei de Acesso à Informação Pública na Colômbia, para em 1951 advir na Finlândia e em 1966 nos Estados Unidos. No restante do mundo, na maioria maciça, o direito à informação veio a ser regulamentado por leis específicas nas décadas de 1990 e 2000. E no Brasil, como se verificará, com a Lei nº 12.527/2011.

2. Todo ser humano tem direito à liberdade de opinião e expressão; este direito inclui a liberdade de, sem interferência, ter opiniões e de procurar, receber e transmitir informações e idéias por quaisquer meios e independentemente de fronteiras. 
Acrescentando-se ao Sistema de Proteção dos Direitos Universais, cita-se ainda a Declaração Conjunta Anual dos Relatores da ONU, OEA e OSCE para a Liberdade de Expressão, a Declaração Inter-Americana de Princípios para a Liberdade de Expressão (2000), a Convenção de Aarhus (2001), a Declaração de Princípio para a Liberdade de Expressão na África (2002), e a decisão da Corte Inter-Americana de Direitos Humanos no caso Claude Reyes, (2006), sobre a importância desse direito universal e inconteste ${ }^{3}$.

De fato, para o Supremo Tribunal Federal - STF (2008), um dos 2 pilares da a democracia é o da informação em plenitude e de máxima qualidade.

O direito à informação deve ser visto de forma interdisciplinar, considerando ser corolário para o exercício pleno da democracia. Com efeito, no sistema participativo o acesso às informações tem caráter público, em face do interesse coletivo. Portanto, trata-se de direito individual e coletivo e um dever do Estado de prestá-lo e garanti-lo.

A Declaração sobre o Direito e a Responsabilidade dos Indivíduos, Grupos ou Órgãos da Sociedade de Promover e Proteger os Direitos Humanos e Liberdades Fundamentais Universalmente Reconhecidos, da ONU de 1998, proclama em seu art. $6^{\circ}$ a amplitude desse direito, em conhecer, procurar, obter, receber e guardar informação sobre todos os direitos humanos e liberdades fundamentais, por meio do acesso à informação, bem como de publicitar, comunicar ou divulgar livremente junto de terceiros, opiniões, informação e conhecimentos sobre todos os direitos humanos e liberdades fundamentais; ou ainda, o direito de formar e defender opiniões.

3. Em 2008, o direito à informação vem novamente a ser reconhecido como direito fundamental, quando a Declaração de Atlanta - produzida durante a conferência internacional no Carter Center, em Atlanta, na Geórgia (EUA), de 27 a 29 de fevereiro de 2008 - sustentou veemente que o acesso a informações tem status idêntico ao de outros direitos humanos. Saliente-se ainda que em 2011 o Brasil aderiu à Open Government Partnership (OGP) ou Parceria para Governo Aberto que visa debater e trocar experiências sobre as melhores práticas em abertura de informações para a sociedade, em transparência nas ações do governo e sobre os novos caminhos para a governança pública no século XXI. O Decreto s/n de 15 de setembro de 2011 instituiu o Plano de Ação Nacional sobre Governo Aberto.
0 direito à informação situa-se no plano dos novos direitos fundamentais do cidadão, compreendido direito da quarta geração4 ao lado do direito à democracia e do direito ao pluralismo (BONAVIDES, 2001, p. 74-78).

A denominação "direito à informação" envolve a conexão entre duas realidades: direito e informação, e no dizer de Joaquín Urías (2009, p. 15), se trata de uma denominação extremamente vaga na hora de definir seus conteúdos. E mais, "la información es una realidad amplia, él derecho más y el Derecho de la información, así dicho, inabarcable”.

Nesse contexto o direito à informação deve tomar um conceito mais abrangente que a simples "obtenção ou divulgação de informação” pelo cidadão. Uma definição atual denota uma ideia de conhecimento amplo e participativo de informar, de se informar e de ser informado; ou ainda nos termos da ADPF $n^{0} 153$, "direito à verdade".

Canotilho e Moreira (1993, p. 189) aduzem que:

0 direito à informação [...] integra três níveis: o direito de informar, o direito de se informar e o direito de ser informado. 0 primeiro consiste, desde logo, na liberdade de transmitir ou comunicar informações a outrem, de as difundir sem impedimentos, mas pode também revestir de forma positiva, enquanto direito a informar, ou seja, direito a meios para informar. 0 direito de se informar consiste designadamente na liberdade de recolha da informação, de procura de fontes de informação, isto é, no direito de não ser impedido de se informar. Finalmente, o direito de ser informado é a versão positiva do direito de se informar, consistindo num direito a ser mantido adequadamente e verdadeiramente informado, desde logo, pelos meios de comunicação [...] e pelos poderes públicos [...].

0 direito à informação, portanto, consiste no conjunto de direitos das pessoas naturais e jurídicas divulgarem, conhecerem e receberem dos órgãos públicos informações de seu interesse particular, ou de

4. Alguns autores defendem haver esta quarta geração de direitos, em especial Bobbio, mas para este esta geração estaria relacionada à "engenharia genética". (BOBBIO, 1992, p. 6). Há ainda a defesa de uma quinta geração, como defendido pelo próprio BONAVIDES (2001), sendo então o "direito à paz". 
interesse coletivo ou geral, ressalvados àquelas referentes a sigilo, como mecanismo formador da cidadania e do exercício de sua participação. Envolve o direito de saber, o direito de falar e o direito de ser ouvido.

Em outras palavras, direito de informação é o conjunto de direitos da pessoa, decorrente da liberdade de expressão, em informar, ser informado e de se informar de assuntos de seu particular ou de interesse público, ressalvadas as exceções de sigilo, e como elemento formador e integrativo da cidadania participativa.

Salienta-se, ainda, que direito à liberdade de expressão leva em seu significado o direito à informação, e desse se extrai muitos outros significados como o direito de participação e democracia, por exemplo; com conteúdo difuso e interdisciplinar.

Também, há de ser diferenciado o direito à informação pública ou coletiva e o direito à informação individual ou privada, protegida pela CF (art. $5^{\circ}, \mathrm{X}$ ), e regulamentado em leis, como na própria LAI. Com efeito, o interesse da coletividade fica limitado à proteção do indivíduo, como pessoa humana e sujeito de direitos indisponíveis.

Por outro lado, também, não se pode olvidar que as novas tecnologias e o infinito conhecimento proveniente da internet faz com que o direito à informação tome um lugar de relevância e destaque no conjunto dos direitos humanos. Neste caso, na vivência na Era da Informação e a existência de uma busca por uma pós-modernidade dos direitos humanos, à expressão "acesso à informação" são agregados outros valores fundamentais, de conteúdo polissêmico. E cada um desses conceitos nessa pluralidade de significados tem sua própria legitimidade, e que por sua vez pode abrigar um outro conceito ou valor.

\subsection{DIREITO À INFORMAÇÃO NO BRASIL}

Em que pese a existência do Freedom of the Pres Act (1766) e da Declaração Francesa dos Direitos do
Homem e do Cidadão (1789), somente com a Constituição de 1934 houve a previsão para o cidadão ter acesso a informações que a ele se referiam, bem como dos “negócios públicos” (art. 113, 35).

Assim, como as Constituições de 1824 e de 1891, a Constituição de 37 nada dispôs sobre o direito à informação, para somente em 1946, com a redemocratização, novamente surgir o direito - ainda de forma tímida - para conferir a "ciência aos interessados dos despachos e das informações a que eles se refiram" (art. 141, § 36, II), e excluindo da terminologia ampla sobre "negócios públicos" da Carta de 34.

As Cartas de 1967 e 1969 preconizaram o direito do cidadão de obter "prestação de informações independentemente de censura”, "nos termos da lei” (art. 153, § $8^{\circ}$ ).

Verifica-se desse comparativo histórico-constitucional a necessidade de uma norma regulamentadora quanto ao direito de informação contidas nas Constituições de 34, 46, 67 e 69, e confirmada pelo Constituinte de 1988.

Anterior à Constituição vigente, os Códigos de Processo Penal e Penal Militar entendem que a ação penal é pública como regra, a Lei de Abuso de Autoridade (Lei n $4.898 / 65$ ) não trouxe em sua proteção a violação ao direito de acesso à informação; o Código de Processo Civil de 1973 apenas permite a consulta do processo às partes (art. 155) e o Decreto $n^{0}$ 79.099/77 regulamentou hipóteses de sigilo.

Logo, a garantia direta ou indireta do direito à informação ficou condicionada ao surgimento de normativo que o concretizasse. Destarte, o constituinte pátrio não definiu o direito à informação, limitando-se a reconhecê-lo como fundamental, embora já declarasse a necessidade de regulamentaçã $0^{5}$.

5. CF: Art. $5^{\circ}, \mathrm{XIV}$ - é assegurado a todos o acesso à informação e resguardado o sigilo da fonte, quando necessário ao exercício profissional;

Art. 37, II - o acesso dos usuários a registros administrativos e a informações sobre atos de governo, observado o disposto no art. $5^{\circ}, \mathrm{X}$ e XXXIII;

Art. $216,2^{\circ}$ - Cabem à administração pública, na forma da lei, a gestão da documentação governamental e as providências para franquear sua consulta a quantos dela necessitem. 
Registra-se, portanto, trata-se de uma norma de eficácia limitada à medida que depende de complementação e não contém todas as informações necessárias para a sua perfeita compreensão. Segundo o art. $5^{\circ}$ da CF:

XXXIII - todos têm direito a receber dos órgãos públicos informações de seu interesse particular, ou de interesse coletivo ou geral, que serão prestadas no prazo da lei, sob pena de responsabilidade, ressalvadas aquelas cujo sigilo seja imprescindível à segurança da sociedade e do Estado.

0 que abrangem informações de "interesse particular" ou de "interesse coletivo"? O que se deve entender por "órgãos públicos"? Quais as hipóteses de sigilo "indispensável à segurança da sociedade e do Estado”?

Então surge a maior indagação. Se as informações serão prestadas "nos prazos da lei", sem a existência desse normativo, o direito à informação é garantido de maneira plena?

Uadi Lammêgo Bulos (2011, p. 608) pontua que o art. $5^{\circ}$, XXXIII da CF "contém matéria das mais polêmicas de nossa Constituição".

Após a Constituição de $88^{6}$, o Decreto n $99.347 / 90$ alterou o Decreto $n^{0} 79.099 / 77$ que disciplinava assuntos sigilosos.

Com a Lei de Arquivos Públicos (Lei $n^{0}$ 8.159/91, arts. $4^{\circ}, 5^{\circ}, 22$ a 24), o direito e 0 acesso à informação foram garantidos, mas ainda se estabelecia que o acesso e a consulta seriam disciplinados por "lei"7.

Outro avanço foi a Lei de Habeas Data (Lei $n^{0}$ 9.507/97), mas que também possui aplicação restrita, relacionado à obtenção de informações personalíssima do impetrante ${ }^{8}$.

6. Destacam-se outros normativos, como o Código de Defesa do Consumidor (arts. 51, IV, X e XIII e 52, II e V), sobre a necessidade de informação adequada em relação a vários aspectos dos contratos; o direito a informações conferido aos advogados por meio da Lei no 8.906/94 (art. $7^{\circ}$ ); a exibição de documentos (arts. 355, 798, 799, 844, II, CPC), exemplificando.

7. A Lei de Obtenção de Certidões (Lei no 9.051/95) advém para a defesa de direitos e esclarecimentos de situações, no entanto, tem aplicação restrita.

8. Para o STJ (2007), "embora o art. $5^{\circ}$, XXXIII, da Carta Magna de 1.988 tutele o direito à informação, de interesse particular ou coletivo, não se pode afirmar que o habeas data
A Lei de Processo Administrativo (Lei no 9.784/99) e a Lei de Responsabilidade Fiscal (LC n 101/2001 e alterada pela Lei Capiberibe) ainda que importantes normativos, que traduzem o princípio da Publicidade, não asseguravam ou disciplinam o direito à informação de forma ampla9.

Posteriormente, em 2005, advém a Lei nº 11.111 que, no entanto, regulamentou apenas a parte final do inciso XXXIII do art. $5^{\circ}$ da CF.

Registrava-se faltar, assim, uma norma ampla e/ ou complementar e integradora de outras normas que disciplinavam o direito à informação.

A nova Lei de Acesso à Informação - Lei $n^{0}$ $12.527 / 2011^{10}$, de 18 de novembro de 2011 - surge com o intuito de regulamentar esse direito à informação e trazer profundas mudanças de paradigmas no desenvolvimento ou aperfeiçoamento de uma cultura de transparência, pois tem o objetivo de facilitar o direito fundamental e universal à informação (CANELA; NASCIMENTO, 2009).

Há de se ressaltar que a LAI não revoga os normativos já existentes que tratam da matéria ${ }^{11}$, mas busca aperfeiçoá-los na garantia ao acesso da informação, disciplinando obrigações, procedimentos, prazos e responsabilização (MOTA JR, 2013), além de incentivar e fomentar a ideia de "cultura de transparência" ou "cultura de acesso", como defendido pela Controladoria-Geral da União - CGU (2011).

O advento da nova Lei de Acesso à Informação, sem dúvida, trará profundas mudanças de paradig-

o resguarde. Deveras, o direito à informação abrange os mais variados temas, como, in casu, o direito de petição junto a Administração Pública; enquanto que o habeas data visa assegurar o acesso à informações pertinentes a própria pessoa do impetrante e desconhecidas pelo mesmo."

9. Não se pode deixar de destacar o Portal de Transferência Publica criado e administrado pela Controladoria-Geral da União no âmbito do Poder Executivo Federal e outros tantos Portais de Transparência, anteriores e posteriores à Lei Complementar n 131/2009 (Lei Capiberibe)

10. No âmbito federal, encontra-se ainda regulamentada pelo Decreto $n^{0} 7.724 / 2012$, enquanto cabe aos Estados, ao Distrito Federal e aos Municípios, em legislação própria, definir regras específicas (art. 45, LAI)

11. Registra-se ter revogada a Lei no $11.111 / 2005$ e arts. 23 e 24 da Lei $n^{\circ} 8.159 / 91$ pela nova lei já abranger o tema. 
mas não apenas para a sociedade, como também para a Administração Pública, fazendo com que gestores e servidores públicos mudem suas atitudes no que diz respeito ao cuidar e disponibilizar as informações públicas e educacionais. Implementar-se-á uma difusão à "cultura de transparência" e publicidade ampla (MOTA JR, 2012).

A LAl é de âmbito nacional, em que pese alguns dos seus dispositivos valerem somente para a esfera federal, apresentando diretrizes para todos os entes federativos. Ao estabelecer que o acesso à informação pública é regra, reforça a exceção do sigilo, como as informações de caráter pessoal ou de segurança do Estado.

Resumidamente, a LAI pode ser estruturada em 3 grandes pilares: a) acesso à informação: direito fundamental e dever do Estado, com suas exceções; b) procedimentos de transparência e divulgação; e c) responsabilidades e proteções.

Restringindo-se este trabalho no que toca à ideia do direito fundamental, saliente-se que o acesso à informação, também, está baseado nos princípios da transparência e da publicidade, de modo a facilitar este acesso e tratamento mais público das informações e documentos.

O sigilo no Estado Democrático de Direito sempre deve ser levado com reserva e exceções.

Em sendo a divulgação e a publicidade deveres do Estado, com base na própria CF, a LAI trouxe apenas 2 exceções à regra de acesso: dados pessoais e informações classificadas como sigilosas por serem imprescindíveis à segurança do Estado ou da sociedade, hipóteses estas taxativas. Importante registrar que a classificação do sigilo não é permanente e apenas transitória, com prazos fixos e estabelecidos, a saber: reservado ( 5 anos), secreto (15 anos) e ultrassecreto (25 anos, renovável uma única vez). Outrossim, não poderão ser objeto de restrição de acesso as informações ou documentos que versem sobre condutas que impliquem violação dos direitos humanos, nem negado acesso à informação necessária à tutela judicial ou administrativa de direitos fundamentais, como em investigações criminais e ordens judiciais ${ }^{12}$.

\section{DIREITO À INFORMAÇÃO E O ACESSO A DOCUMENTOS PÚBLICOS DA DITADURA MILITAR}

\subsection{A JURISDIÇÃO CONSTITUCIONAL E A PROTEÇ̃̃O DE DIREITOS}

Conceituar e definir as funções da jurisdição constitucional não é matéria fácil, e longe de ser pacificada.

A teoria montesquieuniana de divisão de poderes e a ideia de lei de Rousseau fizeram com que a Constituição Francesa de 1791 expressamente proibisse dos Tribunais interpretarem o Poder Legislativo. No entanto, com Hans Kelsen ${ }^{13}$, a criação de um Tribunal Constitucional como órgão ad hoc destinado a realizar o controle de constitucionalidade ganha fôlego. A partir de então, poder-se-ia afirmar surgir a ideia de jurisdição constitucional - com base no judicial review norteamericano -, que para o mestre austríaco significava "a garantia jurisdicional da Constituição", e "um elemento do sistema de medidas técnicas que têm por fim garantir o exercício regular das funções estatais” (KELSEN, 2007, p. 123/124).

Surgia a ideia de conferir poderes a órgão jurisdicional (constitucional) realizar o controle das leis e demais atos ao texto constitucional.

Salienta Belaunde (2001, p. 169) que quando se começa a discutir o problema em nível teórico em que se fala em jurisdição constitucional ou "justiça constitucional", tem-se como ponto de partida o famoso texto de Kelsen de 1928, em que ambas as palabras são utilizadas indistintamente e indiferenciadas.

12. Note-se que há expressa disposição na lei de que as leis especificas que tratam de sigilo continuam em vigência, como no caso dos segredos de justiça, industrial e defesa nacional.

13. Ressaltam-se os embates travados com Carl Schmitt (1983) que defendia ser o guardião da Constituição o Presidente do Reich e não o Tribunal de Justiça Constitucional. 
Neste momento, Kelsen se preocupa em justificar um controle de constitucionalidade e em saber porque esse controle não poderia ser realizado pelo Parlamento. Para tanto, haveria de existir um tribunal ad hoc, fora do Poder Judiciário e sem qualquer dependência com os demais poderes para o exercício do controle de constitucionalidade.

Noutra vertente, diferenças entre os principais sistemas jurídicos existentes, também, influencia na função dessa jurisdição. Como parâmetro-regra, a jurisdição constitucional americana seria concreta e a posteriori, de influência do common law, enquanto a europeia abstrata e alguns casos ex ante, de influência romano-germânico. Nessa visão, a jurisdição europeia demonstraria ser mais política que a americana, todavia, percebe-se ser esta que recebe mais questionamentos. De igual sorte, os diferentes sistemas jurídicos imprimirão uma visão mais expansiva ou limitada das funções da jurisdição constitucional.

Noutro lado, este trabalho não pretende discutir a relação entre as jurisdições ordinária e constitucional, sobretudo na Europa quando se optou a favor dos Tribunais Constitucionais - a partir do desenho de Kelsen - e a complexa relação com a jurisdição ordinária (SEGADO, 2005) ou quem poderia realizar esta jurisdição constitucional, seja por meio de um mecanismo concentrado, seja por meio difuso.

Por certo, a garantia jurisdicional imprime à rigidez constitucional um poder - e dever - de se impor perante as demais leis e ao resto do ordenamento jurídico (CARBONEL, 2010). Consequentemente, a jurisdição constitucional garante a supremacia e a integridade da Constituição.

Mas quem deve cumprir a Constituição? A quem se deve recorrer na proteção de seus preceitos e princípios?

Ronald Dworkin (2001, p. 43) a partir da ideia de Jonh Marshall, no sentido de que se a Constituição é a lei fundamental, entende que todos devem segui-la, inclusive os juízes. No entanto, o "enigma" reside no fato de saber o que a Constituição "veda" ou "proíbe" ao legislador. Começa então a questionar como os juízes conheceriam essa "intenção" do constituinte, motivo pelo qual, "a intenção e o processo são ideias nocivas porque encobrem essas decisões substantivas com a piedade processual e finde que elas não foram tomadas" (DWORKIN, 2001, p. 43).

Isto porque, a "ideia de uma compreensão constitucional original, portanto, não pode ser o início, nem o fundamento de uma teoria da revisão judicial", considerando que o conceito de intenção constitucional é limitado e "aberto a muitas e diferentes concepções rivais” (DWORKIN, 2001, p. 52).

De fato, de uma forma ou de outra, o órgão de julgamento constitucional tem um papel de mediação entre o Estado e o cidadão, na busca por uma "justeza”. Outrossim, fatores como a forma de alteração da Constituição e a designação/nomeação dos juízes desse órgão também contribuem para uma análise diferenciada dessa função (ROSENFELD, 2007, p. 260).

De qualquer modo, deve-se entender que a "prestação jurisdicional [substantiva no Direito] é uma questão de princípio" (DWORKIN, 2001, p. 137).

Nessa visão, a diferença da composição do Supremo quando do julgamento RMS no 23.036 do STF e da ADPF $n^{0} 153$ poderia eventualmente alterar o entendimento, assim como o momento e a realidade social, em 2006 e 2010. Ou mesmo como se portaria a Corte julgar o tema, após o advento da LAl e da Comissão Nacional da Verdade.

A VII Cúpula Ibero-Americana de Cortes Supremas e de Tribunais Superiores de Justiça buscou destacar os princípios e direitos da função jurisdicional: justiça transparente, justiça compreensível, justiça atente a todos, justiça responsável perante o cidadão, justiça ágil e tecnologicamente avançada e justiça que protege aos mais vulneráveis. 
Verifica-se que todos convergem para a proteção de direitos e da democracia.

Em sendo uma das funções da jurisdição constitucional, pelo aspecto formal ou material, limitar e controlar o exercício do poder público, sua relação com os direitos fundamentais e com a democracia formam um conjunto indissociável, pois se complementam, integram, cooperam, e quase por dizer, se fundem.

Não se pretende afirmar que somente a jurisdição constitucional realizará essa limitação e controle sobre o poder público, mas essa função se torna uma marca - e importância - dos tribunais constitucionais contemporâneos.

A proteção de direitos fundamentais pela jurisdição constitucional parece ser algo inconteste. No entanto, as dimensões, limitações, execuções e efeitos da decisão são variáveis no tempo e no espaço e não apenas na ordem constitucional vigente.

Os contextos político, histórico, econômico e social, sem dúvida, influenciam a tomada de decisão pelo órgão constitucional e na sua própria interpretação.

Não poderia ser outro pensamento considerando que os direitos fundamentais não são estáticos, mas sim dinâmicos e mutáveis.

Na proteção de direito, a jurisdição constitucional torna-se mais relevante ante "omissões inconstitucionais" entendidas por Jorge Miranda (2012, p. 1) como comportamentos omissivos, sejam essas omissões provenientes de atos normativos, sejam de atos de conteúdo não normativo ou individual e concreto.

No caso estudado, a falta ou deficiência de norma específica ou ampla que garanta o direito à informação ante a regulamentação do art. $5^{\circ}$, XXXIII da CF configuraria uma omissão legislativa, entendida como "a falta de medidas legislativas necessárias, falta esta que pode ser total ou parcial" (MIRANDA, 2012, p. 13), que por sua vez seria não institucional, por ser relativa a um direito fundamental ou a uma incumbência do Estado.

Se as instituições públicas não garantem ou restringem os direitos, a jurisdição constitucional pode representar a suas efetivações.

\subsection{A GARANTIA DO ACESSO A DOCUMENTOS PÚBLICOS DA DITADURA MILITAR}

Na deficiência normativa ou na ausência de lei mais completa sobre a matéria, como seria garantido então o direito à informação quanto ao acesso a documentos públicos da ditadura militar? Quais os documentos estariam abrangidos por sigilo? Como distinguir o público do privado? Como restaria o “direito à memória” ou o "direito à verdade”? Quem poderia garantir o direito fundamental?

A análise do Recurso Ordinário em Mandado de Segurança $n^{0} 23.036$ do STF e da ADPF nº 153 são fundamentais para buscar responder a essas indagações.

Inicialmente, o direito à verdade tem normativamente no Direito Internacional humanitário, relacionado à situação de pessoas mortas e desaparecidas em conflitos armados internacionais (Convenções de Genebra, Protocolo I, art. 32 e 33, de 19497; e Resolução ONU 2005/66 - Right to the truth), e também previsão no art. 25 , relativo à Proteção Judicial, da Convenção Americana dos Direitos do Homem (1969), bem como a Resolução 2175/2006 (Right to the truth) da Assembléia Geral da Organização dos Estados Americanos.

Com bases nesses normativos, extraem-se 2 dimensões do direito à verdade: 0 direito das vítimas e de seus familiares a conhecer a verdade, seja sobre as circunstâncias da detenção, do desaparecimento, da morte ou da localização dos restos mortais e o direi- 
to da sociedade à construção da memória, história e identidades coletivas (PINTO, 2011) ${ }^{14}$.

Em face dessas restrições à garantia ao direito à informação, buscaram-se na jurisdição constitucional respostas para algumas dessas indagações e proteção do direito fundamental.

No RMS 23.036/RJ, julgado em 2006, os impetrantes tinham o objetivo de acessar fontes a subsidiar elaboração de livro (em homenagem a advogados defensores de acusados de crimes políticos durante determinada época) a partir dos registros documentais e fonográficos de sessões de julgamento público do período da ditadura militar perante o Superior Tribunal Militar. Requeridas cópias dos processos e gravações em áudio, no âmbito administrativo, aquela Corte somente concedeu o direito à informação ao impetrante advogado, nos termos da Lei no 8.906/94 ${ }^{15}$.

Se a democracia se avultar na publicidade e o direito à informação, estes não podem ser restringidos com base em atos de natureza discricionária, "salvo quando justificados, em casos excepcionais, para a defesa da honra, da imagem e da intimidade de terceiros ou quando a medida for essencial para a proteção do interesse público". (STF, 2006). Deste modo, não restou configurada a situação excepcional a limitar a incidência da publicidade dos documentos públicos (segundo os arts. 23 e 24 da Lei no 8.159/91) e do direito à informação.

14. Quanto ao primeiro aspecto, no Brasil, a Comissão Especial sobre Mortos e Desaparecidos - Lei $n^{\circ}$ 9.140/95 - foi criada com o objetivo de reparar as famílias de uma lista inicial de 136 pessoas e julgar outros casos apresentados para seu exame, além de empreender esforços na localização de restos mortais de pessoas desaparecidas. Já Comissão de Anistia - Lei no 10.559/02 -, no âmbito do Ministério da Justiça, tem a finalidade de examinar os requerimentos de reparação econômica, de caráter indenizatório, aos anistiados políticos que sofreram prejuízos em razão de perseguições políticas, no período de 1946 a 1988. O segundo aspecto, todavia, carecia de normativo específico para o acesso a documentos públicos da ditadura militar, considerando-se tratar de um direito da sociedade. Com efeito, a Lei da Anistia (Lei $n^{\circ}$ 6.683/79) não disciplinou o assunto. Com base ainda nos art. 23 e 24 da Lei $n^{0} 8.159 / 91$, vigente à época, a sua regulamentação pelo Decreto $n^{\circ} 2.134 / 97$ restringia esse acesso, assim também como se deu no posterior Decreto $n^{\circ} 4.553 / 02$.

15. 0 Relator originário, o Ministro Maurício Corrêa denegou a ordem, e após pedido de vista, o voto vencedor foi do Ministro Nelson Jobim.
Neste aspecto em particular, a decisão se aproximou do constitucionalismo garantista ${ }^{16}$ defendido por Ferrajoli (2011, p. 104) no qual os juízes não podem criar normas, "mas somente censurar a sua invalidade por violação à Constituição, anulando-as no âmbito da jurisdição constitucional, ou, então, desaplicando-as ou suscitando exceções de inconstitucionalidade no âmbito da jurisdição ordinária”, ao afastar a incidência da Lei nº 8.159/91 e do Decreto n².134/97. Reforça o autor que os direitos fundamentais exigem “leis de atuação", função específica do Parlamento.

Consta da ementa do julgado (STF, 2006) que "a coleta de dados históricos a partir de documentos públicos e registros fonográficos, mesmo que para fins particulares, constitui-se em motivação legítima a garantir o acesso a tais informações".

No voto-vencedor (STF, 2006, p. 280), extrai-se que quando se trata do direito à informação não há espaço para discricionariedade, bem como não se pode dar a uma norma interpretação ampliativa para restringir um direito fundamental, restrição essa que não se pautaria em nenhum princípio constitucional de mesmo valor em nosso ordenamento. Isto porque, o direito fundamental à informação, diante da recente história brasileira, seja talvez um "dos mais caros no elenco do art. $5^{\circ}$ da Constituição".

Saliente-se que nessa linha de pensamento, e no exercício da jurisdição constitucional, destaca-se a discussão sobre a amplitude do mandado na injunção, quando do julgamento do $M I n^{0}$ 284/DF, em $12 / 11 / 1992$, que direta ou indiretamente asseverou o direito à verdade e o direito à informação, e que o sigilo afronta o princípio democrático.

No ajuizamento da ADPF n 153 , o Conselho Federal da Ordem dos Advogados do Brasil alegou, resumidamente, que a Lei de Anistia teria quebrado os princípios

\footnotetext{
16. 0 constitucionalismo garantista, defendido pelo autor, seria um complemento e reforço ao positivismo jurídico, sem pretender superá-lo, uma vez que este "positiva não apenas o 'ser', mas também o 'dever ser' do direito; e do Estado de Direito porque comporta a submissão, inclusive da atividade legislativa, ao direito e ao controle de constitucionalidade" (FERRAJOLI, 2011, p. 100).
} 
da isonomia em matéria de segurança, o da proibição de ocultar a verdade, o republicano, o democrático, e, em especial, o da dignidade da pessoa humana.

Atentando-se para a finalidade deste trabalho, destaca-se 0 argumento de preceito fundamental malferido pela interpretação questionada do $\S 1^{017} \mathrm{da}$ Lei $n^{\circ} 6.683 / 79$ quando o inciso XXXIII do art. $5^{\circ}$ da Constituição assegura a todos o direito à informação. Segundo o argüente, a Lei de Anistia impediu que as vítimas dos agentes de repressão e o povo brasileiro tomassem conhecimento da identidade dos responsáveis pelos atos de agressão e tortura.

0 relator o Min. Eros Grau acompanhado pela maioria julgou a ADPF improcedente em 2010, contudo, firmou-se o entendimento de que o "acesso a documentos históricos como forma de exercício do direito fundamental à verdade" 18 .

O órgão ministerial (STJ, 2010, p. 18), à época, se manifestou no sentido em reconhecer a legitimidade da Lei de Anistia em não ter o significado de apagar o passado, pois, uma Lei de Anistia ampla, geral e irrestrita, significaria, também, prejudicar o acesso à verdade histórica.

0 “acesso à verdade histórica” insere-se, portanto, no conceito de direito à informação, considerado então como "direito fundamental à verdade".

A ADPF n 153 reconhece - e atesta - que a "verdade" consubstanciada no acesso a documentos e informação é um direito fundamental, e como tal, não deve ter embaraços para seu exercício. Protegeu-se

17. Art. $1^{\circ}$ É concedida anistia a todos quantos, no período compreendido entre 02 de setembro de 1961 e 15 de agosto de 1979, cometeram crimes políticos ou conexo com estes, crimes eleitorais, aos que tiveram seus direitos políticos suspensos e aos servidores da Administração Direta e Indireta, de fundações vinculadas ao poder público, aos Servidores dos Poderes Legislativo e Judiciário, aos Militares e aos dirigentes e representantes sindicais, punidos com fundamento em Atos Institucionais e Complementares.

$\S 1^{\circ}$ - Consideram-se conexos, para efeito deste artigo, os crimes de qualquer natureza relacionados com crimes políticos ou praticados por motivação política.

18. Entendeu o ministro-relator que a referida lei não impedia o acesso a informações atinentes à atuação dos agentes da repressão no período militar, e, utilizando-se a manifestação do Procurador-Geral da República afirmou que "impõe-se o desembaraço dos mecanismos que ainda dificultam o conhecimento do quanto ocorreu no Brasil durante as décadas sombrias da ditadura", como consta na ementa do julgado. o direito à informação de forma abstrata e genérica, pois, "o direito à verdade para se saber e se construir e se reconstruir a história compõe a ética constitucional, e haverá de ser respeitada" (STF, 2010, p. 98), como advertiu a Ministra Carmen Lúcia em seu voto.

Logo, a garantia direta ou indireta do direito à informação ficou condicionada ao surgimento de normativo que o concretizasse.

Há de se salientar que um dos argumentos utilizados pelo STF para julgar a citada ADPF improcedente ${ }^{19}$, nesse aspecto do direito à informação, foi o questionamento de constitucionalidade na ADI no 4077 sobre as Leis $n^{0} 8.159 / 91^{20}$ e $11.111 / 05$. Entretanto, registra-se que a LAl expressamente revogou a Lei $n^{\circ}$ $11.111 / 05$ e arts. 23 e 24 da Lei no $8.159 / 91$, então pontos de discussão pela razão do sigilo. Além disso, dias depois da edição da LAI adveio a Lei $n^{0} 12.528$, de 18/11/2011, que criou a Comissão Nacional da Verdade com a finalidade de examinar e esclarecer as graves violações de direitos humanos praticadas no período fixado no militar, a fim de efetivar o direito à memória e à verdade histórica e promover a reconciliação nacional.

Os julgamentos estudados foram anteriores ao advento da LAl, e nesse particular, representa a análise de como a jurisdição constitucional deve estar atenta às mudanças, aos anseios e à realidade social, com cautela.

O STF (2010) considerou a Lei de Anistia recepcionada ao considerar que a "integração da anistia de 1979 na nova ordem constitucional, sua adequação à Constituição de 1988 resulta inquestionável. A nova ordem compreende não apenas o texto da Constituição nova, mas também a norma-origem”.

E na prestação jurisdicional, o STF (2010) como sujeito político-social entendeu que:

A interpretação do direito tem caráter constitutivo e

19. O RMS no 23.036-1/RJ foi tratado como precedente da Corte.

20. Com a Lei de Arquivos Públicos (Lei no 8.159/91, arts. $4^{\circ}, 5^{\circ}, 22$ a 24), o direito e o acesso à informação foram garantidos, mas ainda estabelecia que o acesso e a consulta seriam disciplinados por "lei". 
consiste na produção, pelo intérprete, a partir de textos normativos e da realidade, de normas jurídicas a serem aplicadas à solução de determinado caso, solução operada mediante a definição de uma norma de decisão. A interpretação/aplicação do direito opera a sua inserção na realidade; realiza a mediação entre o caráter geral do texto normativo e sua aplicação particular; em outros termos, ainda: opera a sua inserção no mundo da vida.

5. O significado válido dos textos é variável no tempo e no espaço, histórica e culturalmente. A interpretação do direito não é mera dedução dele, mas sim processo de contínua adaptação de seus textos normativos à realidade e seus conflitos.

Ao se discutir ainda a função da jurisdição constitucional da função legislativa, assentou no julgamento que:

\begin{abstract}
A Constituição não afeta leis-medida que a tenham precedido. 7. No Estado democrático de direito o Poder Judiciário não está autorizado a alterar, a dar outra redação, diversa da nele contemplada, a texto normativo. Pode, a partir dele, produzir distintas normas. Mas nem mesmo o Supremo Tribunal Federal está autorizado a rescrever leis de anistia. 8. Revisão de lei de anistia, se mudanças do tempo e da sociedade a impuserem, haverá - ou não - de ser feita pelo Poder Legislativo, não pelo Poder Judiciário.
\end{abstract}

O diálogo da jurisdição constitucional com outras instituições políticas, também, é aventada por Bruce Ackerman (2006, p. 421) quando afirma que o diálogo institucionalizado entre a Corte e as ramificações políticas permite uma escolha popular mais deliberada que defina a síntese ampla dos princípios do passado e do presente, guiando a República na sua próxima fase de desenvolvimento.

A ADPF n 153, sem dúvida, procurou realizar um diálogo político, histórico e social ao manter a validade da Lei de Anistia e o direito à verdade histórica dos fatos do período militar. Daí, no contexto geral, também deve considerá-la como uma questão de princípio e aprimoramento da democracia ${ }^{21}$.

21. Dworkin, neste aspecto, sustenta que um sistema de decisões terminativas por juízes a respeito de grandes questões de princípio, pode, de fato, aprimorar o caráter democrático da política. O que, nesse ponto é discordado por Jeremy Waldron (2009, p. 249) ou para Dieter Grimm (2006) para o qual "o controle judicial de constitucionalidade é tão inconciliável com a democracia quanto o próprio constitucionalismo".
Nota-se, ainda, que nos julgamentos do RMS 23.036/ RJ e da ADPF n 153 o STF não afirma faltar norma regulamentadora para o exercício do direito à informação, mas utiliza-se de princípios e interpretação para concessão e garantia do direito, como jurisdição constitucional.

\section{CONCLUSÃO}

Algumas indagações levantadas neste trabalho foram respondidas, se tentou responder outras, e outras ainda se mantêm sem respostas. Essa é a mesma visão - ou sensação - que se deve ter sobre a jurisdição constitucional.

A função da jurisdição constitucional é como o magma das placas tectônicas que ora se convergem ou divergem, ora fazem movimentos lentos, ora são expelidas num vulcão ou apenas emitem cinzas. No entanto, é esse magma que sustenta e dá estabilidade à sociedade nela alicerçada, assim como as placas tectônicas sustentam os continentes e oceanos. Não haveria a litosfera se não fosse o magma. 0 magma pode destruir, mas, sobretudo, constrói, como a jurisdição constitucional. A função de construir - e proteger - deve consubstanciar a jurisdição constitucional, como a própria ideia da placa tectônica - do grego tektoniké: "a arte de construir".

Da análise dos julgamentos do Recurso Ordinário em Mandado de Segurança $n^{\circ} 23.036$ do STF e da ADPF $n^{0} 153$ pode-se perceber a função construtora da jurisdição constitucional. Ambos os julgados são anteriores à Lei de Acesso à Informação, e por meio deles, pode-se identificar a importância da jurisdição constitucional na proteção de direitos.

A questão ao envolver a garantia do acesso a documentos públicos da ditadura militar se reporta a princípios constitucionais e basilares da sociedade contemporânea, o que, sem dúvida, está incluído o direito à informação e o direito à verdade. 
0 reconhecimento universal e pátrio do direito fundamental à informação deve ser visto como uma conquista ampla e social, mas não permite afirmar que sua simples "fundamentalização" em textos normativos o torne efetivamente garantido ou assegurado.

Num sistema participativo e "informatizado", o direito à informação é corolário para o exercício pleno da democracia, de modo que as informações sejam em regra públicas, em face do interesse coletivo. Torna-se, portanto, um direito individual e coletivo a ser protegido pela jurisdição constitucional.

\section{REFERÊNCIAS}

ACKerman, Bruce. Nós, o Povo Soberano: Fundamentos de Direito Constitucional. Belo Horizinte: Del Rey, 2006.

BOBBIO, Norberto. A Era dos Direitos. Rio de Janeiro: Campus, 1992.

BONAVIDES, Paulo. Teoria constitucional da democracia participativa (por um Direito Constitucional de luta e resistência, por uma Nova Hermenêutica, por uma repolitização da legitimidade). São Paulo: Malheiros, 2001.

BULOS, Uadi Lammêgo. Curso de Direito Constitucional. 6.ed. São Paulo: Saraiva, 2011.

BRASIL. CONTROLADORIA-GERAL DA UNIÃO. Cartilha “Acesso à Informação Pública”. Brasília: 2011. Disponível em: shttp://www.cgu.gov.br/publicacoes/ CartilhaAcessoaInformacao/index.asp >. Acesso em: 30 nov. 2013.

BRASIL. Supremo Tribunal Federal. Ação de Descumprimento de Preceito Fundamental $n^{0} 153$. Relator: Ministro Eros Grau. Brasília. 29 abr. 2010. Diário de Justiça Eletrônico. Disponível em: <http://www.stf. jus.br/portal/jurisprudencia/listarJurisprudencia.as p?s1=\%28adpf $+153 \% 29 \&$ base $=$ baseAcordaos\&url $=h$ ttp://tinyurl.com/alybl76>. Acesso em: 16 dez. 2013.

BRASIL. Supremo Tribunal Federal. Medida Cautelar em Ação de Descumprimento de Preceito Fundamental no $130 \mathrm{MC} / \mathrm{DF}$, Relator: Ministro Carlos Britto. Brasília. 27 fev 2008. Diário de Justiça Eletrônico. Disponível em: <http://www.stf.jus.br/portal/jurisprudencia/listarJurisprudencia.asp?s1=\%28adpf+13 $0 \% 29$ \&pagina $=3$ \&base=baseAcordaos $>$. Acesso em: 15 dez. 2013.

BRASIL. Superior Tribunal de Justiça. Recurso Especial 781969/ RJ. Relator Ministro Luiz Fux. Brasília. 8 mai. 2007. Diário de Justiça. Disponível em: <https://ww2.stj.jus.br/revistaeletroni$\mathrm{ca} /$ ita.asp?registro $=200501533724 \mathrm{ddt}$ _publicacao $=31 / 05 / 2007>$. Acesso em: 21 dez. 2013.

BRASIL. Supremo Tribunal Federal. Recurso Ordinário em Mandado de Segurança $n^{\circ}$ 23036/RJ. Relator: Ministro Maurício Correa. Relator p/ acórdão: Ministro Nelson Jobim. Brasília. 28 mar. 2006. Diário de Justiça Eletrônico. Disponível em: <http://www.stf.jus.br/ portal/jurisprudencia/listarJurisprudencia.asp?s1=\% 28salvo+quando+justificados\%29\&base=baseAcord aos\&url=http://tinyurl.com/msjsvhr $>$. Acesso em: 17 dez. 2013.

BRASIL. Supremo Tribunal Federal. Mandado de Injunção no 284/DF. Relator: Ministro Marco Aurélio. Relator p/ acórdão: Ministro Celso de Mello. Brasília. 11 nov. 1992. Diário de Justiça Eletrônico. Disponível em: <http://www.stf.jus.br/portal/jurisprudencia/listarJurisprudencia.asp?s1=\%28MI\%24\%2ESCLA $\% 2 \mathrm{E}+\mathrm{E}$ $+284 \% 2 \mathrm{ENUME} \% 2 \mathrm{E} \% 29+\mathrm{OU}+\% 28 \mathrm{MI} \% 2 \mathrm{EACMS} \%$ $2 \mathrm{E}+\mathrm{ADJ} 2+284 \% 2 \mathrm{EACMS} \% 2 \mathrm{E} \% 29 \&$ base $=$ baseAcord aos\&url=http://tinyurl.com/ax9mhv2>. Acesso em: 11 jan. 2014.

CANELA, Guilherme e NASCIMENTO, Solano (coord). Acesso à informação e controle social das políticas públicas. Brasília, DF: ANDI; Artigo 19, 2009. 
CANOTILHO, José Joaquim Gomes; MOREIRA, Vital. Constituição da república portuguesa anotada. 3.ed. Coimbra: Coimbra, 1993.

CARBONELL, Miguel. El neoconstitucionalismo: significado y niveles de análisis. In: CARBONELL, Miguel; JARAMILLO, Leonardo García. El canon neoconstitucional. Madrid: Trotta, UNAM, 2010, p.153-164.

DWORKIN, Ronald. Uma Questão de Princípio. Trad. Luis Carlos Borges. 2.ed. São Paulo: Martins Fontes, 2001.

FERRAJOLI, Luigi. Constitucionalismo garantista $\mathbf{x}$ Neoconstitucionalismo. Tradução de André Karam Trindade. Anais do IX Simpósio Nacional de Direito Constitucional. da Associação Brasileira de Direito Constitucional - ABDConst. Curitiba: ABDConst., 2011.

GRIMM, Dieter. Jurisdição constitucional e democracia. Revista de Direito do Estado. Rio de Janeiro: Renovar, 2006, v.4, p.3-22.

HABERMAS, Jürgen. Direito e democracia: entre facticidade e validade. [1992] v. I. 2.ed. Rio de Janeiro: Tempo Brasileiro, 2003.

KELSEN, Hans. Jurisdição constitucional. 2.ed. São Paulo: Martins Fontes, 2007.

MIRANDA, Jorge Manuel Moura Loureiro. A fiscalização da inconstitucionalidade por omissão, Revista Direito e Liberdade, ESMARN, v.14, n.1, p.9-40, jan./ jun. 2012.

MORAES, Alexandre de. Direito Constitucional. 20.ed. São Paulo: Atlas, 2011.

MOTA JR, João Francisco da. A Lei de Acesso à Informação (LAI) e a Cultura da Transparência. Boletim de Direito Administrativo, São Paulo, v.28, n.9, set. 2012.
MOTA JR, João Francisco da. O Acesso a Informações pelos Candidatos em certames públicos. Revista Prática Jurídica. n.131. Brasília: Consulex, 2013.

PINTO, Julia Kertesz Renault. Direito à Memória e à Verdade o os Direitos Humanos: 0 Caso "Guerrilha Do Araguaia. Coimbra. 2011. Disponível em: <http:// www.fd.uc.pt/hrc/pdf/papers/JuliaKertesz_Ensaio_ VF_PG2011.pdf>. Acesso em: 10 jan. 2014.

ROSENFELD, Miguel. O Julgamento constitucional na Europa e nos Estados Unidos: parâmetros e contrastes. In: TAVERES, Ramos (coord.) Justiça Constitucional: pressupostos teóricos e análises concretas. Belo Horizonte: Fórum, 2007.

SCHMITT, Carl. La Defensa de la Constitución. Madrid: Tecnos S.A., 1983.

SEGADO, Francisco Fernández. El Recurso de Amparo en España como vía de generación conflictual entre el Tribunal Supremo y el Tribunal Constitucional. In: ROCHA, Fernando Luiz Ximenes; MORAES, Filomeno.

Direito Constitucional Contemporâneo - Estudos em homenagem ao professor Paulo Bonavides. Belo Horizonte: Del Rey, 2005, p.211-262.

WALDRON, Jeremy. 0 judicial review e as condições da democracia. Trad. Julia Sichieri Moura. Limites do controle de constitucionalidade. Coleção ANPR de direito e democracia. Antônio Carlos Alpino Bigonha e Luiz Moreira (Orgs.). Rio de Janeiro: Lumen Juris, 2009. 
Recebido em: 15 de Janeiro 2015

Avaliado em: 16 de Janeiro 2015

Aceito em: 22 de Janeiro 2015
1. Mestrando em Direito Constitucional pelo Instituto Brasilense de Direito Público - IDP. Especialista em Processo Civil e Penal-UFBA e Pós-Graduado em Ciências Jurídicas - UCSal/EMAB. Professor da Unieuro (Brasília-DF). Analista de Finanças e Controle - Controladoria-Geral da União, requisitado à Presidência da República. Conselheiro Nacional de Segurança Pública. E-mail: jofram10@yahoo.com.br 